\title{
A Journey to Lake San Martin, Patagonia
}

\section{Author(s): H. L. Crosthwait}

Source: The Geographical Journal, Vol. 25, No. 3 (Mar., 1905), pp. 286-291

Published by: geographicalj

Stable URL: http://www.jstor.org/stable/1776333

Accessed: 27-06-2016 03:08 UTC

\section{Your use of the JSTOR archive indicates your acceptance of the Terms \& Conditions of Use, available at}

http://about.jstor.org/terms

JSTOR is a not-for-profit service that helps scholars, researchers, and students discover, use, and build upon a wide range of content in a trusted digital archive. We use information technology and tools to increase productivity and facilitate new forms of scholarship. For more information about JSTOR, please contact support@jstor.org.

The Royal Geographical Society (with the Institute of British Geographers), Wiley are collaborating with JSTOR to digitize, preserve and extend access to The Geographical Journal 
Loch Dilate.-As compared with Loch Shiel, the most notable features of this loch were: the greater abundance of life, the absence of Holopedium and Diaptomus laciniatus, and the presence of Diaphanosoma brachyurum in considerable numbers. Among the organisms observed were: Diaptomus gracilis, Cyclops strenuus, Synchoeta pectinata, Ploesoma truncata, Dinobryon, Peridinium, two species of Ceratium (C.hirundinella and C.cornutum), Anabcena flos aquae with its adherent Vorticelloe.

Loch Eilt.-Life was abundant, the characteristic animals being Holopedium, Diaptomus laciniatus, Cyclops strenuus, Anurcea cochlearis, Notholca longispina, and Polyarthra. Leptodora and Bythotrephes were scarce. Bosmina obtusirostris and a variety approaching $B$. longispina were seen. The brilliant red and blue Rotifer, Notops pygmceus, was plentiful. Some immature specimens of Diaptomus probably belonged to $D$. gracilis. On the mud in the deepest part of the loch were numbers of a pretty little green larva of an insect, enclosed in transparent flask-shaped cases.

Loch Dubh.-This little loch, remarkable for its great relative depth and temperature conditions, resembling those in a great lake, was examined on two occasions. On the first visit in July, 1902, the surface temperature was $59^{\circ}$ Fahr., while on the second visit in March, 1903, the temperature throughout was about $41^{\circ}$ Fahr. Notwithstanding this difference in temperature there was little difference in the animals observed on the two occasions. Those found in July were: Diaptomus gracilis (blue and red, grey, red, blue), Cyclops strenuus, Bosmina obtusirostris (small, purple), Daphnia lacustris (all pale red), Eurycercus, Polyphemus, Triarthra, Polyarthra, Anurcea cochlearis, Conochilus, Ceratium hirundinella, Dinobryon. In March all the same animals were found, except Polyphemus, and there were in addition a few larvæ of Corethra (phantom larvæ), Notholca foliacea, a second species of Ceratium (C.cornutum-less common in lakes), Mallomonas. A very small form of Asterionella occurred. Near the shore large spheres of Ophridium were found on the weeds. In the mud from the bottom were many Rhizopods of the species Cyphoderia ampulla, Diffugia pyriformis, D. globulosa, and D. arcula. Lobelia and Myriophyllum were growing along the shores.

Loch na Creige Duithe.-As this loch was only examined by means of a net thrown out from the shore, it is probable that some of the pelagic animals may have been missed. The animals seen were: Diaptomus gracilis (reddish), Cyclops strenuus (yellow), Alonopsis elongata, Chydorus sphoricus, Anuroea cochlearis, Bosmina obtusirostris, Arcella vulgaris. A few of the commonest filamentous Algæ and Desmids were seen. Asterionella was scarce.

\section{A JOURNEY TO LAKE SAN MARTIN, PATAGONIA.}

By Captain H. L. CROSTHWAIT, R.E.

ThIs journey was undertaken in connection with the demarcation of the Chile-Argentine boundary. Before, however, landing in Patagonia, we made a short trip through the channels of Tierra del Fuego on board the Argentine cruiser Nuevo de Julio, Captain Quiroga, which had been placed at the disposal of Sir Thomas Holdich.

The first place we touched at was New Year island, a small island situated in lat. $54^{\circ} 59^{\prime} \mathrm{S}$., about 5 miles off the north coast of Staten island. Our object was to visit the magnetic and meteorological observatory established there by the Argentine Government, as a base observatory, in connection with the Antarctic Expedition, then in 


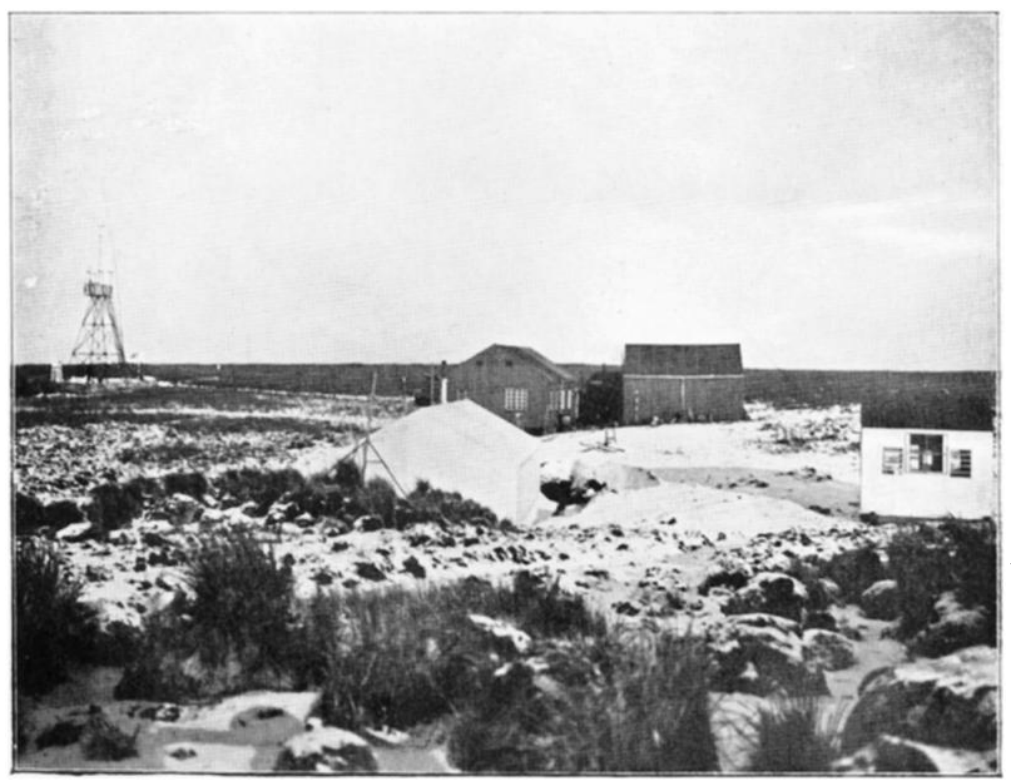

Fig. 1.-MAGNetic aNd METEORological observatory, NeW year island.

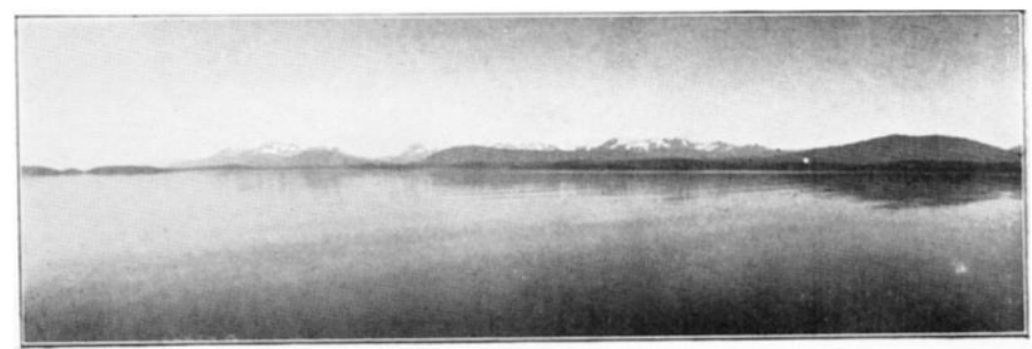

HIG. 2.-BeAGLE CHANNEL.

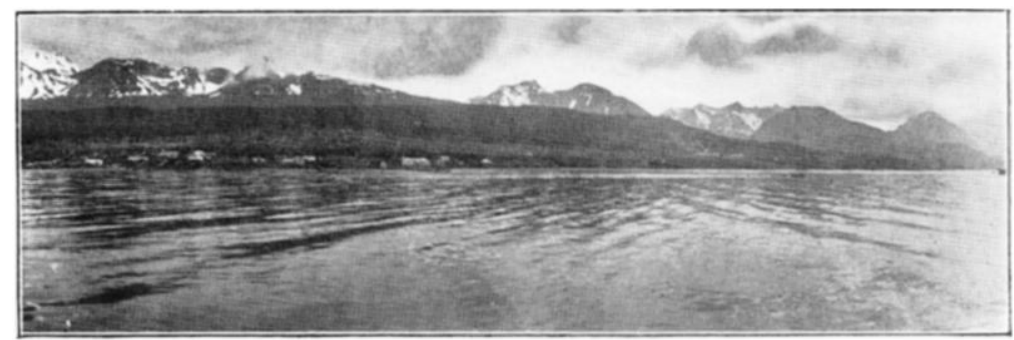

Fig. 3.-UShUAIA, BeAGLE ChanNel. 


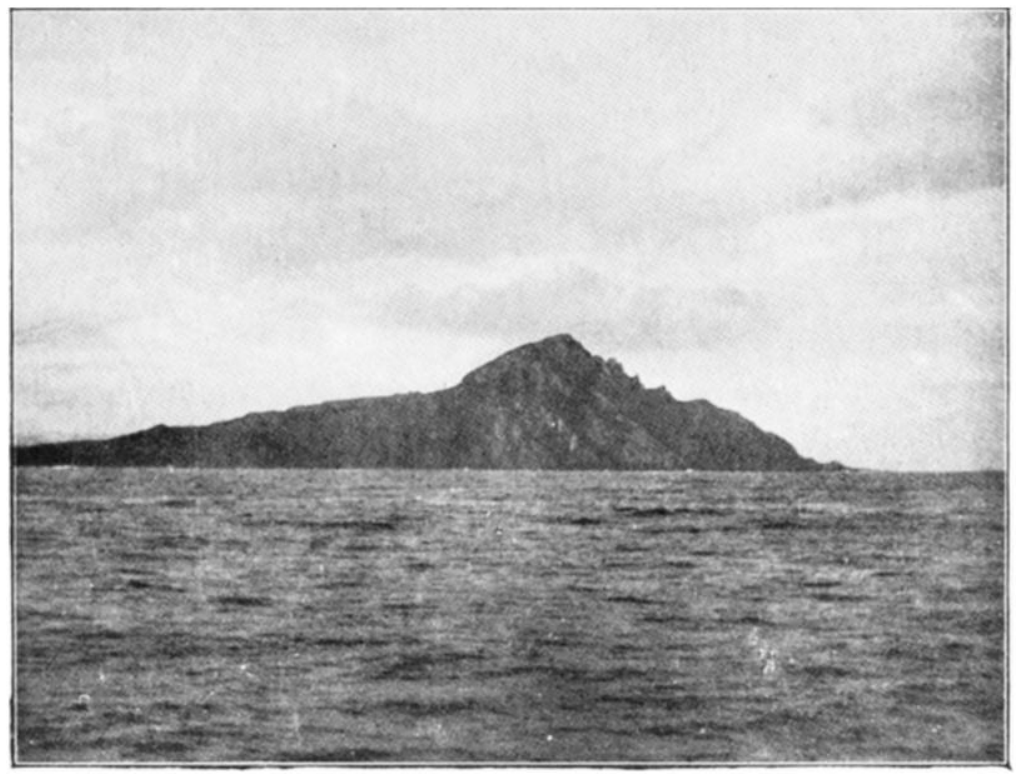

FIG. 4.-CAPE HORN.

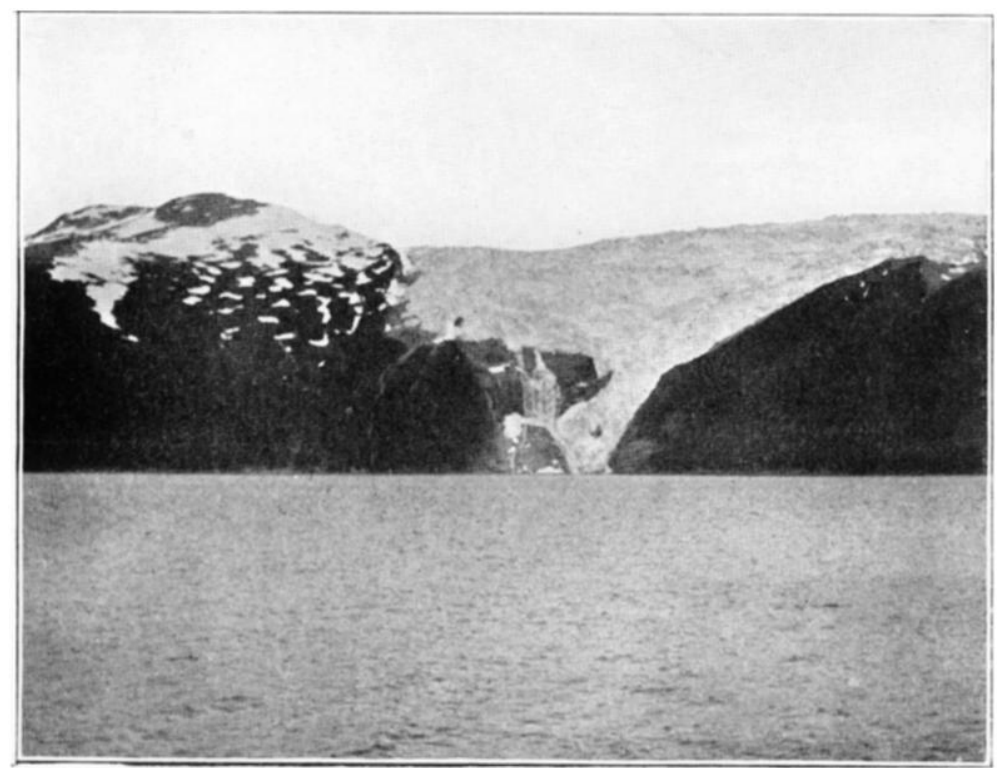

Fig. 5.-GLACIER DESCENDING To THE SEA.

This content downloaded from 198.91.37.2 on Mon, 27 Jun 2016 03:08:43 UTC All use subject to http://about.jstor.org/terms 


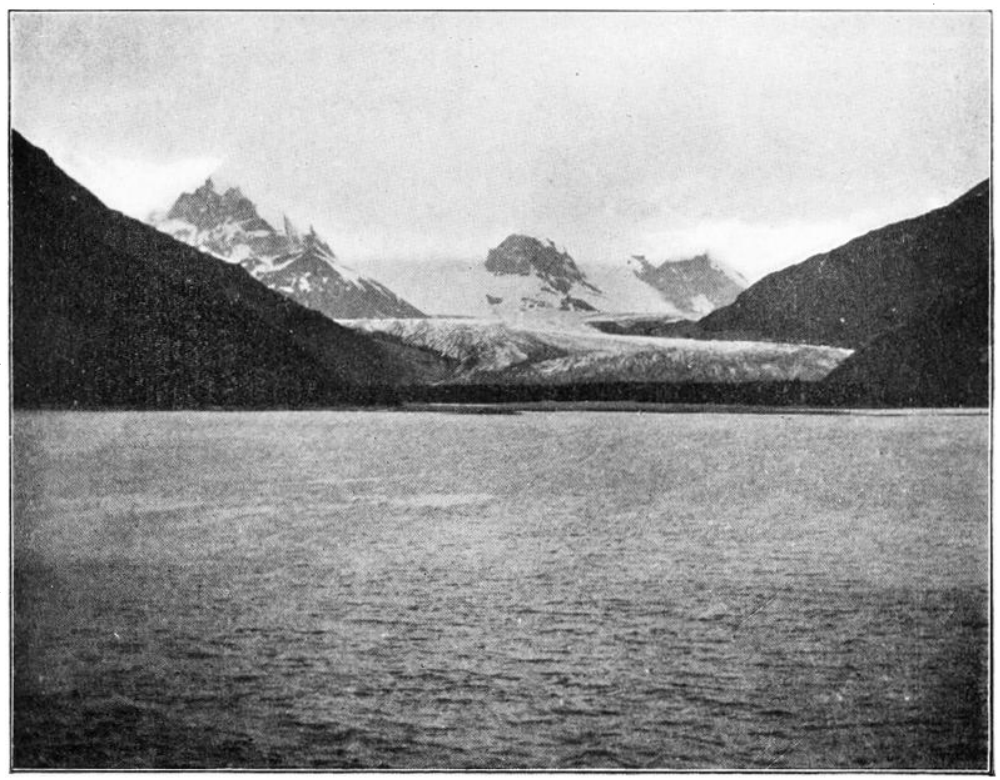

Fig. 6.-ROMANCHE BAY GLACIER, BEAGLE CHANNEL.

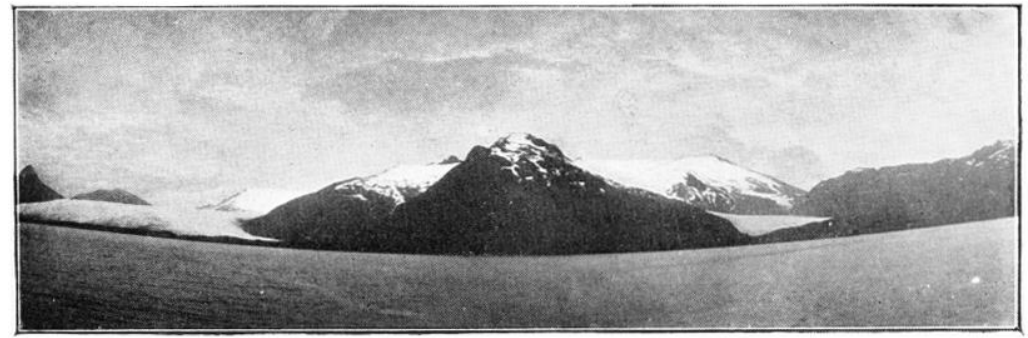

Fig. 7.-GLACLERS DESCENDiNg From MOUNT SARMiento. 
progress under Dr. Nordenskjöld. This is a most complete observatory in every respect. It is superintended by four Argentine naval officers, who, in the interests of science, exile themselves on this lonely and desolate spot. The attention they give to their work is well illustrated by the fact that they never allow the annual range of temperature in the magnetic observatory to exceed $1^{\circ} \mathrm{C}$. The following temperature conditions have been recorded on this island, as given me by the officer in charge, since the observatory was opened in February, 1902: Highest recorded, $55^{\circ} \cdot 4 \mathrm{Fahr}$; ; lowest, $16^{\circ} \cdot 4 \mathrm{Fahr}$.; annual mean, $41^{\circ} \mathrm{Fahr}$. The magnetic observatory is kept at an almost constant temperature of $64^{\circ}$ Fahr.

Staten island was just visible through the mist. An intense gloom, beyond all description, seems to overhang this place, which makes it look like the confines of the world. Entering the Straits of Le Maire, we steamed into Beagle channel, anchoring that night off tine flourishing settlement of Harberton, belonging to Messrs. Bridges, who employ on their farms a number of Ona Indians.

It is not easy to estimate the number of Indians now inhabiting Tierra del Fuego. Mr. Bridges thinks there are about 500 Onas; Mr. W. S. Barclay puts down the Yaghans at 200, and the Alacalufs at 800. This makes a total Indian population of about 1500. Formerly it was estimated at 8000 (' Encl. Brit.'), but it is difficult to believe that such a sterile land, with an inhospitable climate, could have ever supported a large population.

Continuing up Beagle channel, we reached Ushuaia. This place was established a few years ago as a naval station, and is now the seat of the Government of the Argentine portion of Tierra del Fuego. We were here, as elsewhere, most hospitably entertained by the governor.

Shortly after leaving Ushuaia we turned south through Ponsonby sound-the home of "Jemmy Button"-a very narrow channel between Naverine and Hoste islands. In the afternoon we reached Tekineka bay, where the South American Mission has a station and a church-the most southern church in the world. There live here, under the care of Mr. Williams, the missionary, about seventy Yaghan, or canoe Indians.

Leaving this damp and dreary bay, we passed False Cape Horn, and, skirting the west end of Hermite island, made straight for the Horn itself. There was little wind, but a long unpleasant swell was running. Having taken a good look at, and some photographs of, this famous but very ordinary promontory, we turned northward and anchored for the night in Goeree roads, between Naverine and Lennox islands.

The next place of interest was Sloggett bay, where gold-washing is carried on in a most primitive manner by a party of miners, mostly runaway sailors, of various nationalities. Geologically the shores of the bay appear to be formed by the upraised delta of a river, or several rivers, which once flowed into the sea here. These seem now to be 
lost in a great swamp, which covers the alluvial deposit with a thick layer of peat. The sea face is a vertical cliff about 100 feet high. At the base is rock, above this the alluvial deposit, and over all a covering of peat. As the waves undermine the cliff, the gold-bearing gravel falls on the beach below. The sea, acting on the débris like a natural jigger, concentrates the gold a few feet below the surface. This material the miners further concentrate by washing, and thus obtain small quantities of gold-enough, it was said, to provide a living wage. So far as I know, no scientific attempt has been made to deal with this large quantity of gold-bearing material. Whether it would pay is another matter. Owing to its remote existence, and other drawbacks, probably it would not.

The most striking feature of Beagle channel is undoubtedly the astonishing number and variety of the glaciers, which occupy all the valleys descending from every mountain high enough to be covered with a mantle of perpetual snow. The general direction of these valleys is favourable as regards shelter from the summer sun. This fact, no doubt, accounts in a measure for the great extension of the glaciers. The coolness of the summer rather than the severity of the winter is also an important factor in maintaining both the glaciers and the comparatively low snow-line, which cannot be much more than 2000 feet above sea-level. It is to these features we must look in endeavouring to explain the glaciers of Tierra del Fuego.

Most of the larger glaciers we saw showed signs of shrinkage. Trees grow on the lower and older terminal moraines, the vegetation becoming younger as the actual ice-wall is approached. Lateral moraines are found stranded on the flanks of the valleys, high above the present level of the ice, and the polished rock indicates the height to which the glacier had once reached. These features were particularly noticeable in the case of the glacier opposite Romanche bay, and the large glacier descending from Mount Sarmiento. The question of the general recession of glaciers in these regions is an interesting one for future investigation, and Beagle channel forms an admirable field for study.

Navigation is not possible at night in these narrow seas. We therefore anchored every evening in some friendly cove. Often from within the shelter of these deep indentations we heard the storm raging overhead, only occasional and fitful gusts of wind reaching the ship. Now and then the crash of ice falling from neighbouring glaciers resounded among the mountains.

During our stay in Tierra del Fuego from January 15 to the 27th, 1903 (corresponding to July), the mean maximum temperature was $56^{\circ} .2$ Fahr., and the mean minimum $46^{\circ} .7 \mathrm{Fahr}$, as recorded on board ship.

Shortly after landing in Patagonia, at Puerto Consuelo in Last 


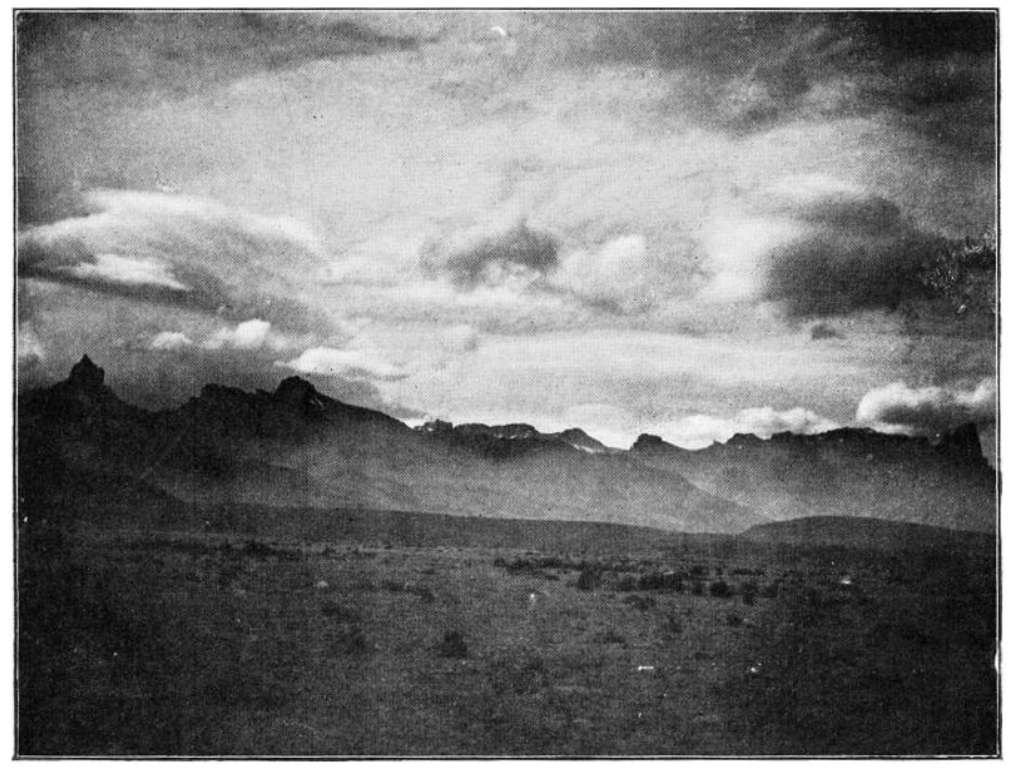

FIG. 8.-BAGUALES RANGE.

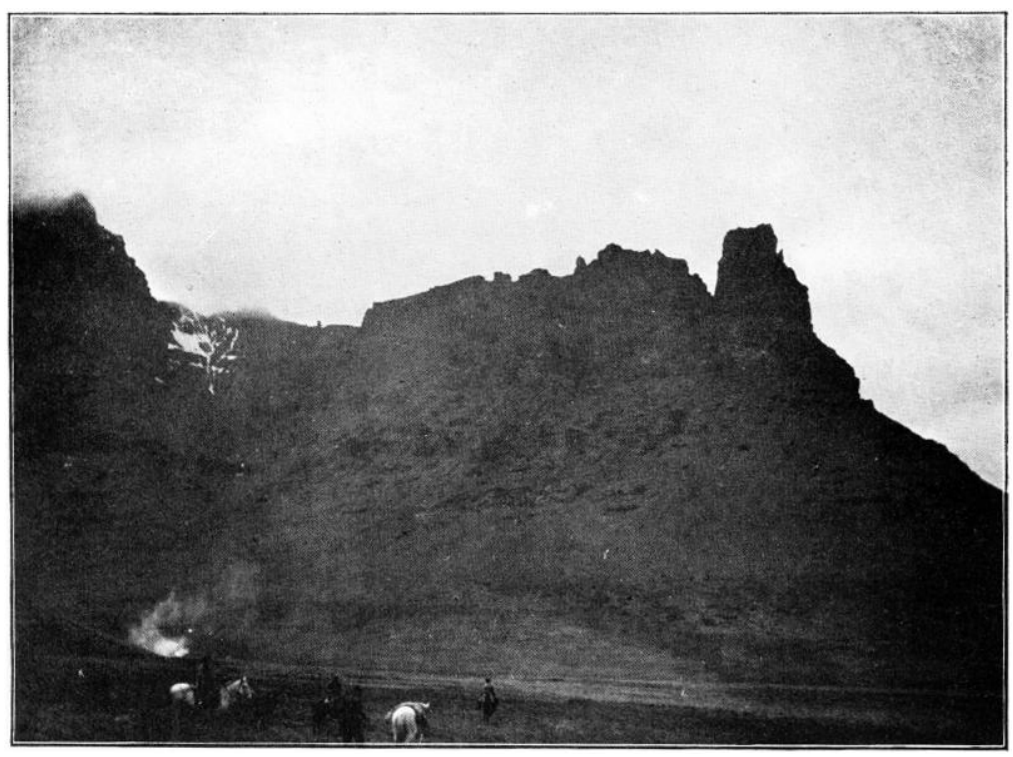

Fig. 9,-BAGUALES RANGE.

This content downloaded from 198.91.37.2 on Mon, 27 Jun 2016 03:08:43 UTC All use subject to http://about.jstor.org/terms 


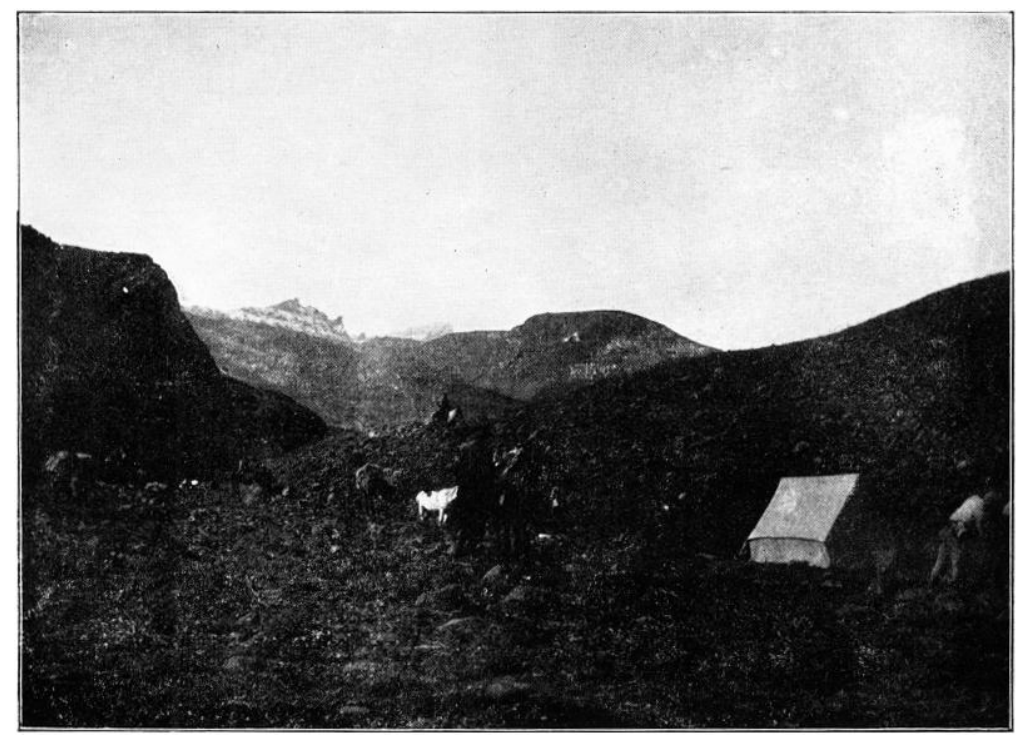

FIG. 10.-CAMP NEAR TOP OF BAGUALES RANGE.

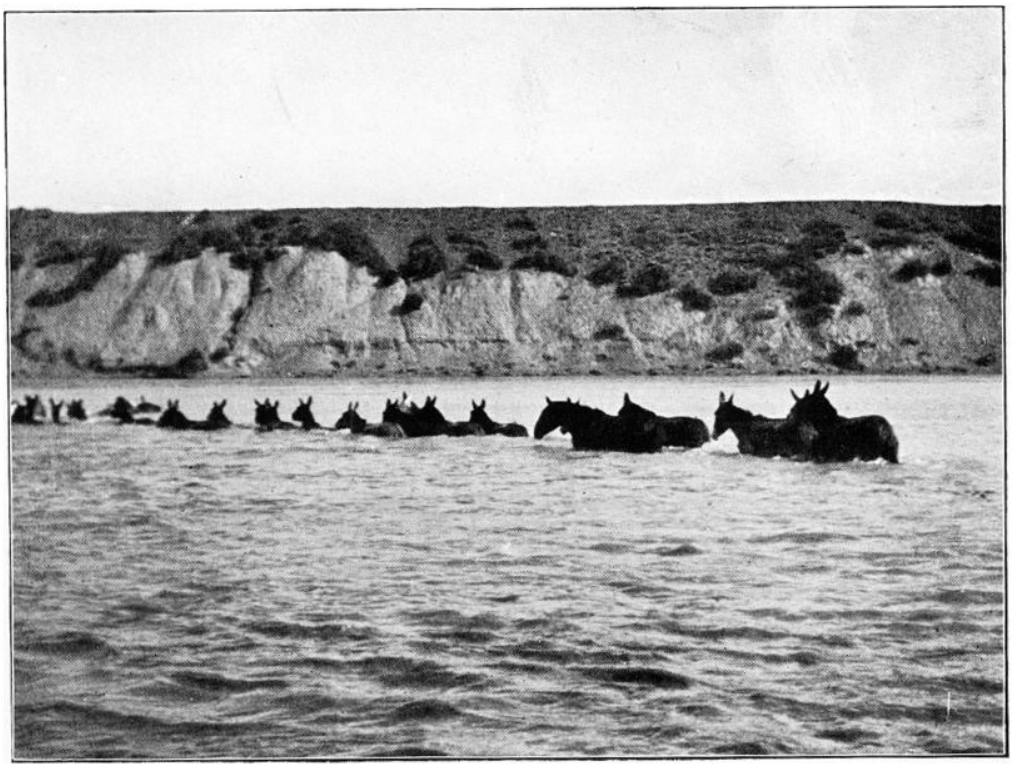

FIG. 11.-RIO SANTA CRUZ.

This content downloaded from 198.91.37.2 on Mon, 27 Jun 2016 03:08:43 UTC All use subject to http://about.jstor.org/terms 


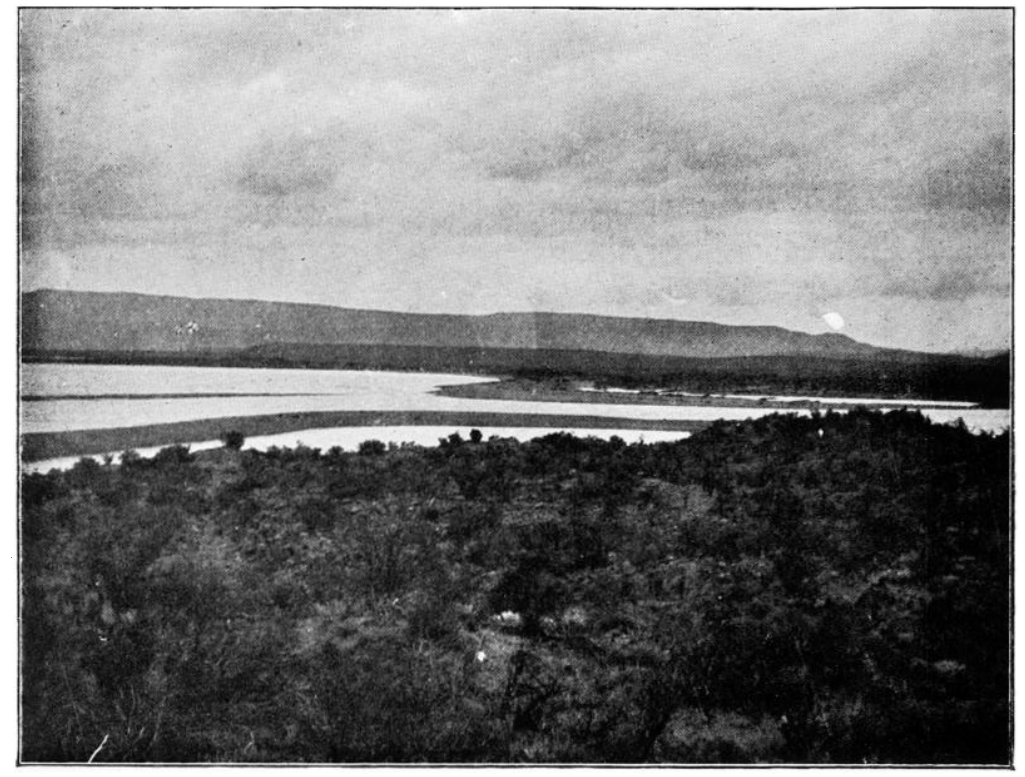

FIG. 12. - NOUTH OF RIO LEONA, I.AKE ARGENTINA.

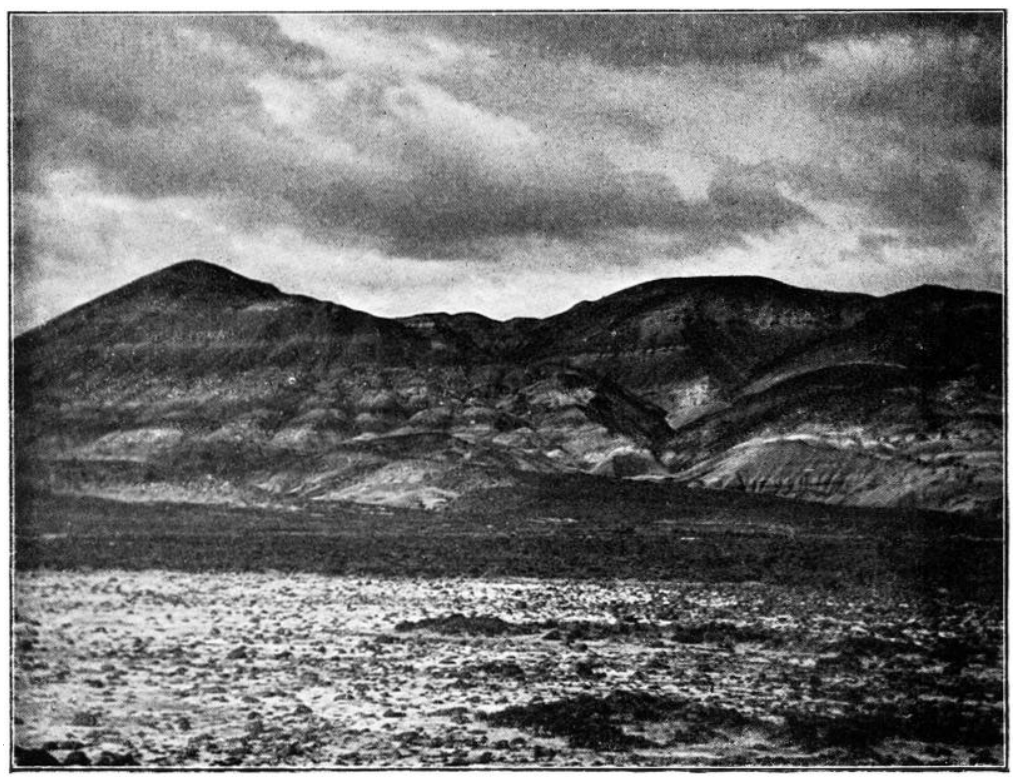

Fig. 13. - ClaA Formation, Rio leoNa.

This content downloaded from 198.91.37.2 on Mon, 27 Jun 2016 03:08:43 UTC All use subject to http://about.jstor.org/terms 
Hope inlet, we visited the now famous Cave of the Mylodon. It is fairly well worked out as regards the larger remains of the giant sloth; there are, however, still to be found pieces of the skin with the hair on of this extinct animal. The explanation of this high state of preservation in which it is found, may be sought in the stalagmite which covers the floor of the cave. There are said to be other caves in the neighbourhood, but the few men who make a business of discovering and disposing of mylodon remains do not encourage exploration.

On February 10, 1903, I left the Chief Commissioner, Sir Thomas Holdich, at Camp Cazador, in lat. $51^{\circ} \mathrm{S}$., and started for Lake San Martin. The route lies across a pass over the Baguales range. This range leaves the continental water-divide in the neighbourhood of Mount Stokes, projecting into the Pampas in a direction almost at right angles to the general line of cordilleras. The formation is basaltic, to which must be attributed its extraordinary appearance. As we entered the narrow valley leading to the pass, high pointed pinnacles and minarets towered above us, assuming all kinds of fantastic shapes and forms-some like vast cathedrals, others resembling mediæval forts. The pass, which is 4100 feet above sea-level, was just free from snow, though patches were lying about in sheltered places.

The march next day was begun in a snowstorm, and during the night the temperature had fallen to $30^{\circ} \mathrm{Fahr}$. However, as we descended the weather cleared, and towards the afternoon we had a splendid view of Lake Argentino. Below us, stretching east and west, lay the great lake, about 60 miles long and 10 to 20 broad. The western end has several arms penetrating deep into the recesses of the cordilleras, and there receive the water of numerous glaciers. Large icebergs were floating on the lake, drifting with the prevailing wind towards the east. Slowly turning round, they exhibited in the glistening sunlight every gradation of colour from blue to green.

In the evening we camped on the shores of a bay. The water was covered with ducks, black-necked swans, and geese. These birds, as indeed all animals in Patagonia, are so unsophisticated from never having seen human beings, that they allow one to approach quite close without attempting to escape. I noticed this partioularly with the huemul round Lake San Martin, but it seemed to be prompted by an insatiable curiosity. Under these circumstances sport, in its true sense, is impossible. Snipe were also fairly plentiful on the shores of the lake. They resemble the English variety, but fly slowly and never very far. I often found them in places high up on the hillsides, quite devoid of water.

The shores of this lake indicate every appearance of its having been much higher at no distant date, probably before the river Santa Cruz, which carries off the surplus water, had cut the deep channel it now occupies. The edge of the bay was strewn with erratic boulders deeply 
scored by ice. These must have been comparatively recently transported from the glaciers of the cordilleras by icebergs and stranded on the shore.

The next march took us to the east end of the lake, where we crossed the Santa Cruz about a mile below where it leaves the lake. The current is very strong, running 7 miles an hour. Though there is plenty of water in this river, its strong stream will always debar it from being used for purposes of navigation, otherwise it would have made a splendid highway to the Atlantic.

Immediately on crossing the river we caught some armadillos. This animal is not found south of the Santa Cruz, but it is very common to the north. It is a good example of the spread of animal life being arrested by a natural feature.

The next march took us up the valley of the Rio Leona, which flows from Lake Viedma into Lake Argentino; thus the Santa Cruz carries off the drainage of these two lakes. Another march brought us to the shores of Lake Viedma. We had a splendid view, which is somewhat rare, of the whole range of the cordillera, including Mount Fitz Roy, the highest peak in this district. Its height is about 11,000 feet. Towards the top it appears to be too steep to hold snow, and looks quite bare.

An enormous glacier descends to the water's edge at the west end of the lake. It emanates from two mountains, one north and one south, in the line of the cordilleras, which are joined by a comparatively low saddle. On to this saddle the glacier descends. Tradition says it here divides in two branches, one going to Lake Viedma and the other reaching the Pacific, somewhere near Eyre sound. It is, however, unexplored, but from appearances this might be the case. If it really happens, the continental water-divide, and consequently the boundary between Chile and Argentine, would follow the surface of an evermoving glacier. From this might result serious embarrassment where already complicated boundary questions exist.

Passing round the east end of Viedma, we crossed a low range into the valley of Lake San Martin. This lake, unlike Viedma and Argentina, has an exit into the Pacific. At the east end of the valley there is a small shallow lake called Laguna Tar. At present its waters flow into Lake San Martin, i.e. in a westerly direction. The continental water-divide is here so ill defined that a cutting of a few feet would cause Laguna Tar to flow to the Atlantic. There is the dry bed of a stream visible, and in time of flood this lake may, temporarily, have an exit in both directions. The continental water-divide would then run through a lake. A water-divide, therefore, without precise knowledge, may prove a very inexact definition for a boundary.

San Martin undoubtedly occupies what was once a strait joining the Atlantic and Pacific. The main body of water runs almost east and west, penetrating into the heart of the cordillera. The mountains rise abruptly from its shores. It is subject to the most violent 


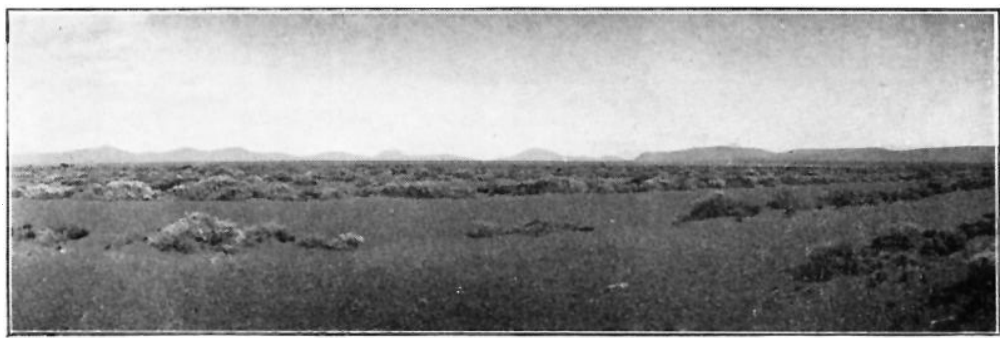

Fig. 14.-PATAGONIAN SCENE.

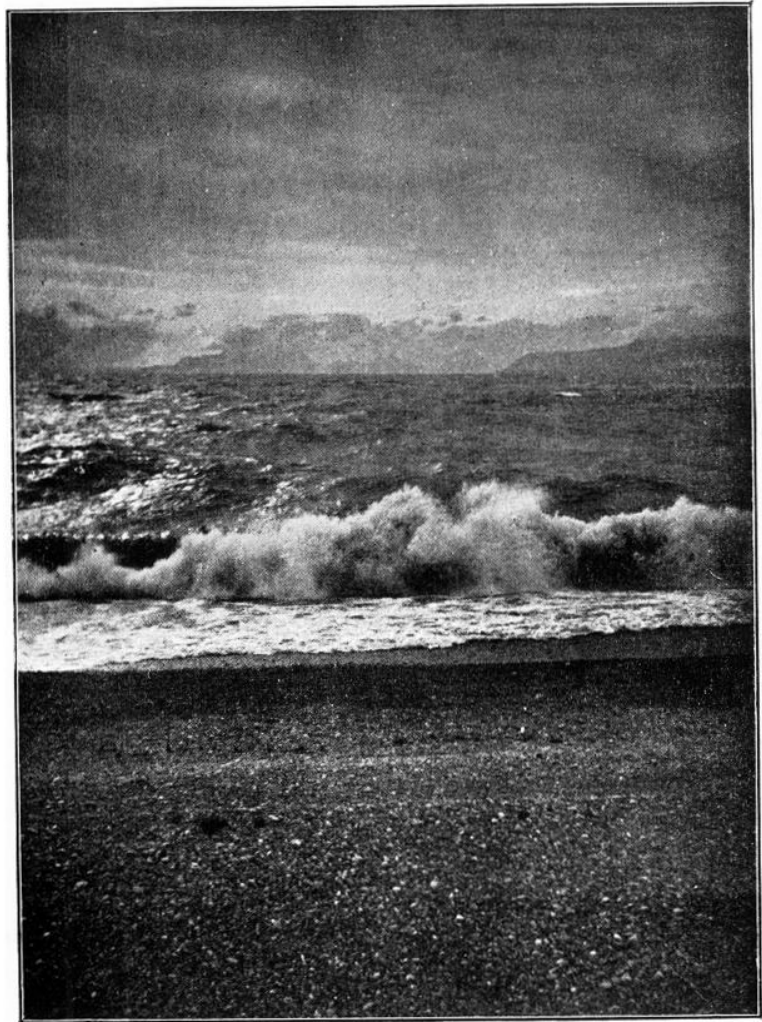

FIG. 15.-WAVES BREAKING ON SHORE OF LAKE VIEDMA.

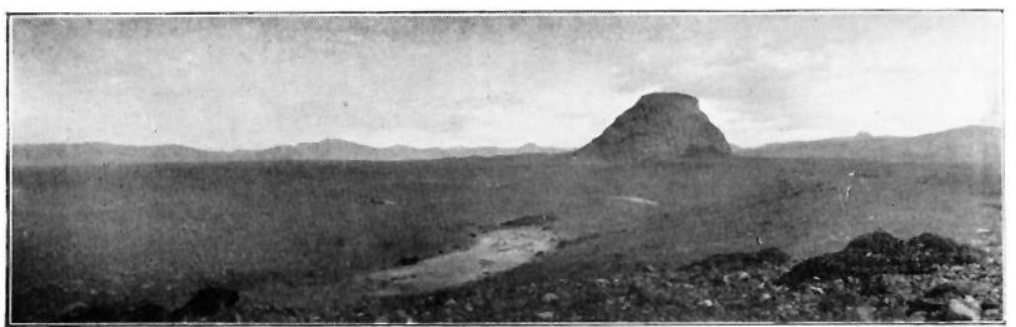

FIG. 16.-MOUNT KOCHAIK VALLEY OF LAKE SAN MARTIN.

This content downloaded from 198.91.37.2 on Mon, 27 Jun 2016 03:08:43 UTC All use subject to http://about.jstor.org/terms 


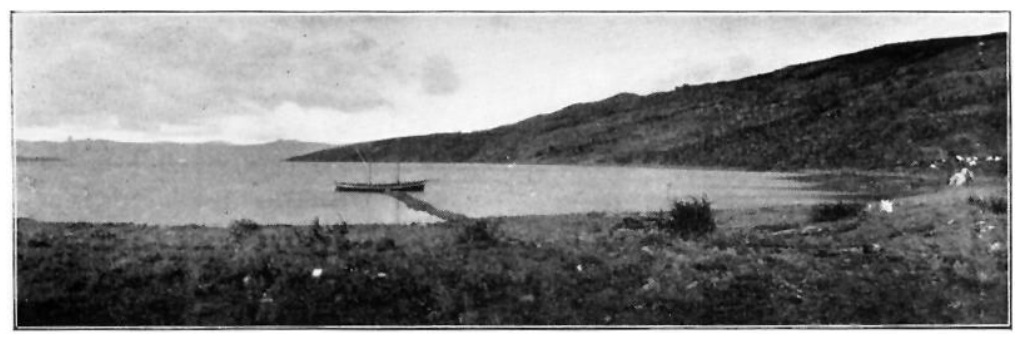

FIg. 17. - BaHIA DEL DEPostTo.

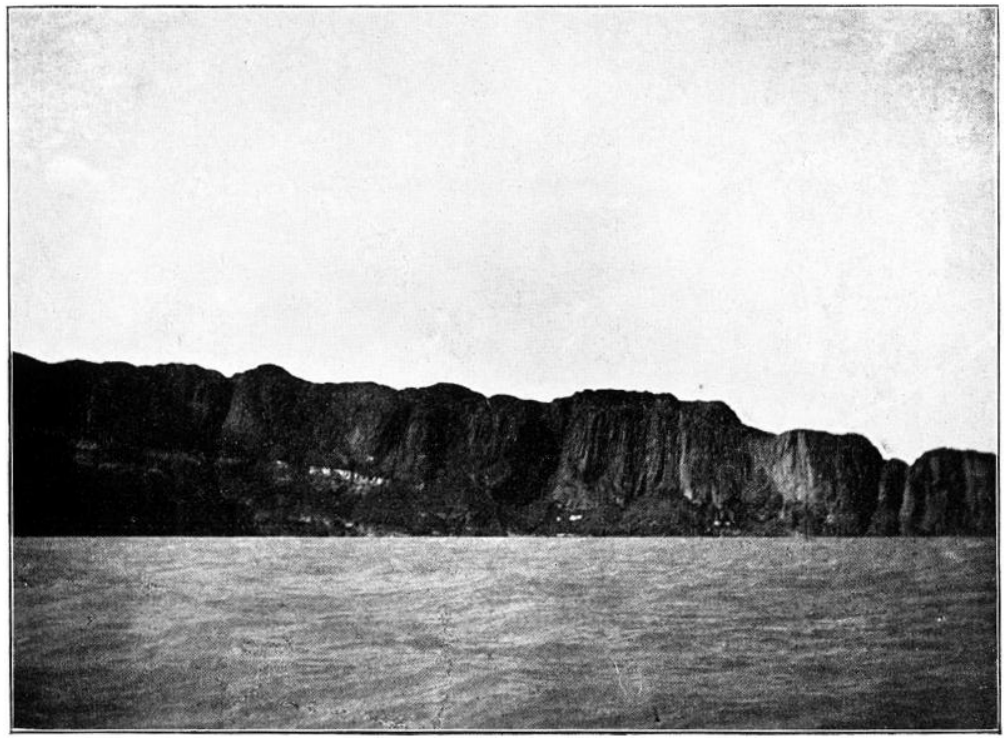

Fig. 18.-Basalt Cliffs, CaNal Chacabuco.

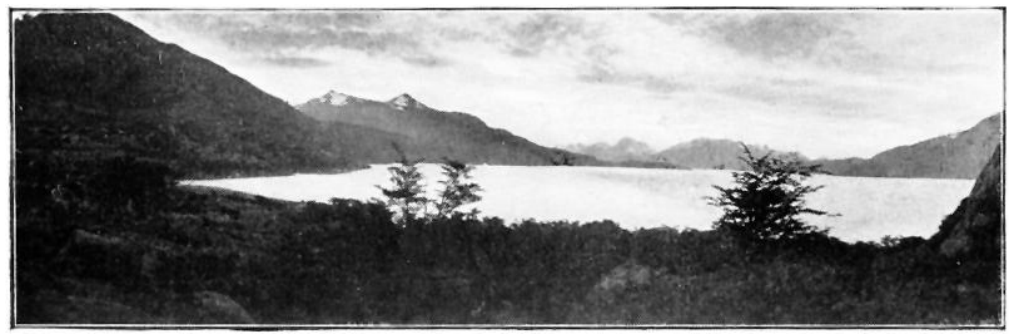

FIG. 19.- VIEW ON LAKE SAN MARTIN.

This content downloaded from 198.91.37.2 on Mon, 27 Jun 2016 03:08:43 UTC All use subject to http://about.jstor.org/terms 
storms, which make the lake very rough and dangerous to navigate, as I have reason to know after a week's expedition on it in a canvas boat.

While encamped on the shores of a sheltered bay, I noticed that the level of the water rose and fell in a peculiar manner. More exact measurements showed that the movements were irregular, but on an average amounted to about 5 inches, having a period of about four minutes between two successive high waters. The surface of the water to the eye was perfectly smooth. I append a diagram of these "seiches," showing 30-second observations extending over half an hour.

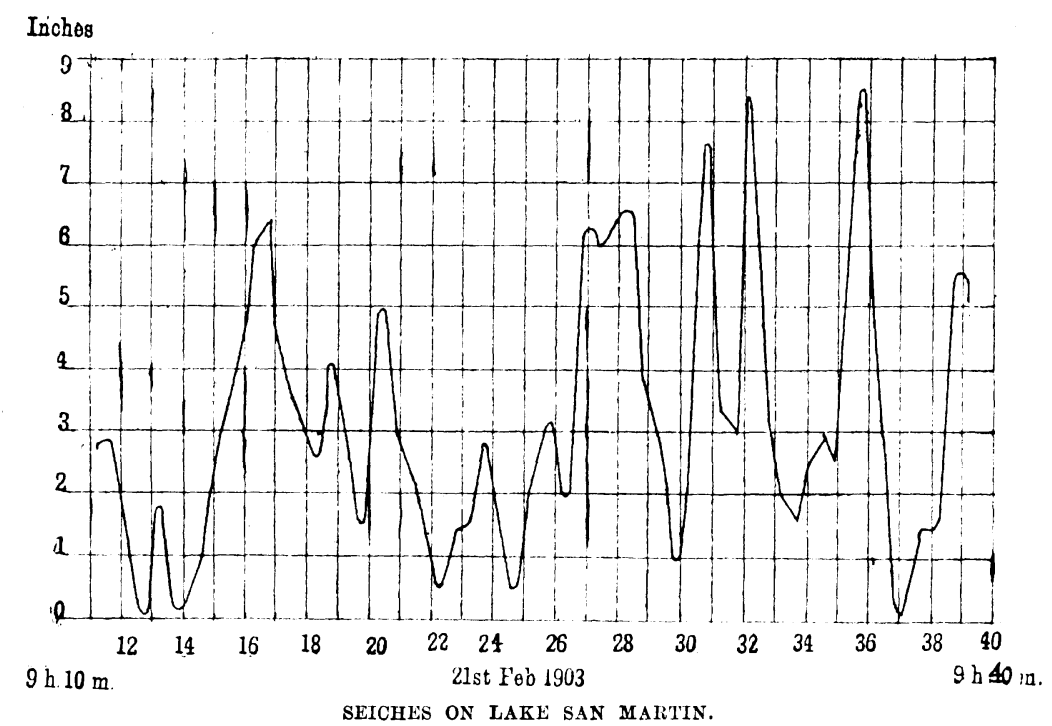

The rocks round San Martin are mostly basalt. In many instances it is cellular, indicating that it had flowed under water. The geological sequence of events here would seem to have been somewhat as follows : A submerged land, when the sites of the great lakes were arms of the sea such as we now find in Tierra del Fuego; volcanic activity, when lava flowed under water, as shown by the existing cellular basalt; elevation of the land, for we find numerous instances of upraised beaches with cellular basalt overlying them; following this another period of volcanic action, and then an age of ice, for there is very marked evidence of ice-action on the basalt. In the present glaciers we have the lineal descendants of a glacial period.

In conclusion, I should like to point out that Patagonia is an excellent field for the traveller who wishes to explore unknown glaciers, and to study glacial action. It is full of interest to the geologist. The climate in summer, though cool, is extremely healthy.

A map illustrating this journey appeared in the February (1904) number of the Geographical Journal, vol. 23, No. 2 . 